\title{
Resistance to Fusarium head blight [Fusarium culmorum (W.G. Sm.) Sacc.] of winter wheat lines generated from crosses between winter type cultivars and resistant spring wheat Sumai 3
}

\author{
Podatność na fuzariozę kłosów [Fusarium culmorum (W.G. Sm.) Sacc.] \\ linii pszenicy ozimej uzyskanych z krzyżowania odmian ozimych \\ z odporną pszenicą jarą Sumai 3
}

\author{
Tomasz Góral ${ }^{1 *}$, Halina Wiśniewska², Dorota Walentyn-Góral ${ }^{1}$, \\ Magdalena Radecka-Janusik ${ }^{1}$, Paweł Czembor ${ }^{1}$
}

\begin{abstract}
Summary
Resistance to Fusarium head blight [Fusarium culmorum (W.G. Sm.) Sacc.] of 52 winter wheat lines was evaluated. The lines were obtained from crosses between three cultivars of winter wheat and resistant spring wheat cultivar Sumai 3. The presence of Fhb1 gene was confirmed in 56\% of lines using the close linked UMN10 marker. The lines showed a very high resistance of type II (for Fusarium spread within the head), while type I resistance (for initial infection) varied. All lines revealed high or very high resistance to Fusarium head blight after inoculation in field experiments. The lines with Fhb1 gene had on average higher resistance, greater plant height and lower grain yield. However, the lines with very high resistance, average height plants and high yields of grain were identified in both groups as well.
\end{abstract}

Key words: winter wheat; Fusarium head blight; Fhb1; resistance

\footnotetext{
Streszczenie wysokim plonie ziarna.

Słowa kluczowe: pszenica ozima; fuzarioza kłosów; Fhb1; odporność

Instytut Hodowli i Aklimatyzacji Roślin - Państwowy Instytut Badawczy Radzików, 05-870 Błonie

${ }^{2}$ Instytut Genetyki Roślin Polskiej Akademii Nauk

Strzeszyńska 34, 60-479 Poznań

*corresponding author: t.goral@ihar.edu.pl
}

Badano odporność na fuzariozę kłosów 52 linii pszenicy ozimej uzyskanych z krzyżowań trzech odmian pszenicy ozimej z odmianą odporną pszenicy jarej Sumai 3. Obecność genu Fhb1 stwierdzono u 56\% badanych linii wykorzystując blisko sprzężony marker UMN10. Linie miały bardzo wysoką odporność typu II (na rozprzestrzenianie się Fusarium w kłosie), natomiast wystąpiło zróżnicowanie odporności typu I (na infekcję pierwotną). Wszystkie badane linie wykazały niską lub bardzo niską podatność na fuzariozę kłosów w infekcyjnych doświadczeniach polowych. Linie z genem Fhb1 miały średnio wyższą odporność, większą wysokość roślin oraz niższy plon ziarna. W obu grupach linii zidentyfikowano jednakże formy o bardzo wysokiej odporności, średniej wysokości roślin oraz 


\section{Wstęp / Introduction}

Fuzarioza kłosów jest chorobą zbóż powodowaną przez grzyby z rodzaju Fusarium. Grzyby te porażają kłosy powodując następnie porażenie i uszkodzenie ziarniaków, a także skażenie tkanek oraz ziarna toksynami fuzaryjnymi (Snijders 2004). Gatunki Fusarium produkują liczne metabolity wtórne zwane mikotoksynami należące do różnych grup chemicznych. Najważniejszą grupą ze względu na liczbę związków oraz powszechność występowania w ziarnie zbóż są trichoteceny (Bottalico i Perrone 2002).

Odporność na grzyby z rodzaju Fusarium powodujące fuzariozę kłosów ma złożoną etiologię. Zidentyfikowano kilka typów (mechanizmów) tej odporności (Mesterhazy i wsp. 1999; Foroud i Eudes 2009). Zostały one opisane jako: typ I - odporność na infekcję pierwotną; typ II odporność na rozprzestrzenianie się Fusarium w kłosie (Schroeder i Christensen 1963); typ III - odporność na porażenie ziarniaków przez Fusarium; typ IV - tolerancja na fuzariozę kłosów i toksyny (Mesterházy 1995); typ V odporność na kumulację toksyn fuzaryjnych w ziarnie przez: 1 - chemiczną modyfikację toksyn (Kluger i wsp. 2015), 2 - blokowanie syntezy toksyn (Boutigny i wsp. 2008).

Odporność pszenicy na fuzariozę kłosów jest cechą ilościową (Bai i wsp. 2000). Odnotowano obecność licznych loci cech ilościowych (quantitative trait loci - QTL) związanych z odpornością na tę chorobę. Przy pomocy markerów molekularnych zidentyfikowano na każdym chromosomie pszenicy (z wyjątkiem 7D) przynajmniej jeden QTL tego typu (Buerstmayr i wsp. 2009). QTL-e wyjaśniające stosunkowo dużą zmienność w obrębie opisywanej cechy zlokalizowano na chromosomach 2DL, 3BS, 4B, 5AS i 6B (Buerstmayr i wsp. 2009). Wspomniane loci pochodzą ze źródeł azjatyckich, jak np. Sumai 3, Wuhan 1 i Nyubai oraz z Brazylii - Frontana. Jednym z najbardziej efektywnych genów odporności na fuzariozę kłosów jest Fhbl (dawniej oznaczony, jako Qfhs.ndsu$3 B S$ ) pochodzący $\mathrm{z}$ odmiany Sumai 3, który w różnych badaniach był w stanie wyjaśnić od 15 do 55\% zmienności odnośnie rozprzestrzeniania się patogena $\mathrm{w}$ tkankach (typ odporności II) (Buerstmayr i wsp. 2009). Gen ten determinuje również odporność na toksyczne działanie deoksyniwalenolu (DON) poprzez kodowanie transferazy glukozowej DON-u lub regulację ekspresji tego enzymu (Lemmens i wsp. 2005). Zgodnie z publikowanymi wynikami tylko Fhbl wykazuje stabilny wpływ na odporność typu II i $\mathrm{V}$ w różnych środowiskach i dla różnych podłoży genetycznych, podczas gdy inne QTL-e dają słaby lub niestabilny efekt (Anderson i wsp. 2007).

Wprowadzenie genu Fhbl pozwala na istotne podniesienie poziomu odporności biorcy (np. wysoko plonującej odmiany pszenicy) na fuzariozę kłosów (Buerstmayr i wsp. 2008). Źródłem genu odporności jest najczęściej odmiana pszenicy jarej Sumai 3 lub formy pokrewne (Buerstmayr i wsp. 2002). Niestety odmiana ta wnosi wiele cech niekorzystnych pod względem agronomicznym, a dodatkowo występują trudne do przełamania sprzężenia genu Fhbl z innymi genami warunkującymi te cechy (Mesterházy i wsp. 2008). Trudności związane $z$ wprowadzaniem genów odporności na fuzariozę kłosów powodują, że mimo wieloletnich prac zarejestrowano nieliczne komercyjne odmiany pszenicy z genem Fhbl (Anderson i wsp. 2015; Van Sanford i wsp. 2016). Są to jedynie odmiany pszenicy jarej. Brak jak na razie zarejestrowanych odmian pszenicy ozimej, co wynika z faktu, że wszystkie źródła genów odporności na fuzariozę kłosów o wysokim efekcie to formy jare.

Rozwiązaniem problemu niekorzystnych cech wnoszonych przez źródła odporności może być selekcja wspomagana markerami (marker assisted selection - MAS) (Czembor i Słowacki 2014). Metoda ta pozwala na wprowadzenie genu odporności Fhbl do genotypów o wysokiej wartości agronomicznej i uniknięcie równoczesnego wprowadzania cech niekorzystnych. Wyżej wspomniane odmiany pszenicy jarej zostały uzyskane dzięki stosowaniu MAS. Prace nad pszenicą ozimą prowadzone są w wielu krajach, w tym w Polsce, w Instytucie Hodowli i Aklimatyzacji Roślin - Państwowym Instytucie Badawczym.

Celami badań były: ocena odporności linii pszenicy ozimej powstałych $\mathrm{z}$ krzyżowania odmian ozimych z pszenicą jarą Sumai 3; określenie obecności genu Fhb1 w badanych liniach; określenie wpływu obecności genu Fhbl na odporność linii oraz na inne cechy fenotypowe, takie jak np. wysokość, wczesność i plon ziarna.

\section{Materiały i metody / Materials and methods}

\section{Materiał roślinny / Plant material}

Materiał badawczy stanowiły 52 linie pszenicy ozimej (pokolenie $\mathrm{F}_{10}$ ) uzyskane z krzyżowań z odmianą pszenicy jarej Sumai 3 (linie S) oraz odmiany/linie wzorcowe (odporne - 20828, A40-19-1-2, Arina, Fregata, UNG 136.6.1.1; podatne - SMH 8694, SMH 8816; Tonacja) (tab. 1).

Tabela 1. Pochodzenie linii S oraz odmian i linii wzorcowych

Table 1. Origin of ' $S$ ' lines and standard cultivars and lines

\begin{tabular}{c|c|c}
\hline $\begin{array}{c}\text { Lp. } \\
\text { No. }\end{array}$ & $\begin{array}{c}\text { Linie/odmiany } \\
\text { Lines } / \text { cultivars }\end{array}$ & $\begin{array}{c}\text { Rodowód } \\
\text { Pedigree }\end{array}$ \\
\hline 1 & 2 & 3 \\
\hline 1 & $\mathrm{~S} 1-\mathrm{S} 7$ & Begra $(=$ Grana $\times$ Bezostaja 1$) \times$ Sumai $3(=$ Funo $\times$ Taiwanmai $)$ \\
\hline 2 & $\mathrm{~S} 8-\mathrm{S} 29$ & Korweta $(=$ CHD-3672-72-77 $\times$ Gama $) \times$ Sumai 3 \\
\hline 3 & $\mathrm{~S} 30-\mathrm{S} 59$ & Turnia $[=($ Polanka $\times$ DED-739-75 $) \times($ Polanka $\times$ TAW-6505-74 $)] \times$ Sumai 3 \\
\hline 4 & $20828^{1,3}$ & Capo $\times$ Sumai 3 \\
\hline
\end{tabular}




\begin{tabular}{c|c|c}
\hline 1 & 2 & 3 \\
\hline 5 & A40-19-1-2, & Capo $\times$ SVP 72017-17-5-10-1 \\
\hline 6 & Arina $^{2,3}$ & Moisson $\times$ Zenith \\
\hline 7 & Fregata & Kobra $\times$ Astron \\
\hline 8 & ${\text { UNG } 136.6 .1 .1^{2,3}}^{3}$ & $($ Sagvari $\times$ Nobeokabozu $) \times($ Mini-Mano $\times$ Sumai 3) \\
\hline 9 & SMH $8694^{3}$ & SMH 7297 $\times$ Rapsodia \\
\hline 10 & SMH $8816^{3}$ & SMH 7293 $\times$ Rapsodia \\
\hline 11 & Tonacja & Jubilatka $\times$ SMH 8134 \\
\hline
\end{tabular}

${ }^{1}$ Buerstmayr i wsp. 2008, ${ }^{2}$ Buerstmayr i wsp. $1999,{ }^{3}$ Góral i wsp. 2015b

Linie S były w ciągu kilku lat selekcjonowane w doświadczeniach infekcyjnych w kierunku odporności na fuzariozę kłosów. Oceniano również odporność linii na inne patogeny, takie jak Blumeria graminis (DC.) E.O. Speer f. sp. tritici Em. Marchal (maczniak prawdziwy) i Puccinia triticina Erikss. \& Henn (rdza brunatna). Rdza żółta (Puccinia striiformis Westend) na pszenicy ozimej pojawiła się w Radzikowie w roku 2014, jednakże nie obserwowano jej występowania $w$ tym roku na liniach S. Dodatkowymi kryteriami selekcji były: wysokość roślin i podatność na wyleganie. Linie/pojedynki wysokie, wylegające lub podatne na patogeny powodujące choroby liści były odrzucane.

\section{Doświadczenia polowe / Field experiment}

Odporność na fuzariozę kłosów 52 linii pszenicy testowana była w warunkach polowych w Instytucie Hodowli i Aklimatyzacji Roślin - Państwowym Instytucie Badawczym w Radzikowie (województwo mazowieckie) oraz w Instytucie Genetyki Roślin Polskiej Akademii Nauk w Poznaniu (pole doświadczalne Cerekwica, województwo wielkopolskie). Doświadczenia polowe zostały założone w październiku 2014 roku w układzie losowanych bloków. Pszenica wysiana była na poletkach o powierzchni 0,5 (Cerekwica) lub $1 \mathrm{~m}^{2}$ (Radzików) w trzech powtórzeniach oraz w kombinacji kontrolnej (nieinokulowanej).

Do produkcji inokulum wykorzystano trzy izolaty Fusarium culmorum (KF 846, KF 350 i ZFR 112). Metodyka produkcji inokulum oraz pochodzenie izolatów zostało opisane w pracy Wiśniewskiej i wsp. (2014). Kłosy pszenicy $\mathrm{w}$ fazie kwitnienia opryskiwano zawiesiną zarodników o stężeniu $5 \times 10^{5}$ zarodników/ml w ilości około $100 \mathrm{ml}$ zawiesiny na $1 \mathrm{~m}^{2}$. Inokulacja prowadzona była oddzielnie na każdym poletku na początku kwitnienia (BBCH 60) i powtarzana około 3 dni później w fazie pełni kwitnienia (BBCH 65). Inokulacje prowadzone były w godzinach wieczornych, kiedy wzrastała względna wilgotność powietrza. W Cerekwicy w celu uzyskania wysokiej wilgotności powietrza zastosowano po inokulacji przez $72 \mathrm{~h}$ mikrozraszacze, utrzymujące wysoką wilgotność powietrza. W Radzikowie doświadczenie prowadzono bez mikrozraszaczy, jednakże pole doświadczalne umiejscowione jest w pobliżu rzeki i obszar ten charakteryzuje się wysoką wilgotnością względną powietrza.

Ocenę rozpoczęto około 10 dni po ostatniej inokulacji. Przeprowadzono dwie oceny w odstępach 7-dniowych. Nasilenie fuzariozy kłosów było określane na podstawie proporcji porażonych kłosków w kłosie (tylko w kłosach z objawami choroby) oraz proporcji kłosów porażonych na poletku. $\mathrm{Z}$ tych wartości został wyliczony indeks fuzariozy kłosów (IFK):

$$
\begin{gathered}
\mathrm{IFK}=(\% \text { porażonych kłosków } \mathrm{w} \text { kłosie } \times \% \text { kłosów } \\
\text { porażonych na poletku }) / 100
\end{gathered}
$$

Dodatkowo w Radzikowie określono plon ziarna linii S z $1 \mathrm{~m}^{2}$ na poletkach kontrolnych po zbiorze za pomocą kombajnu poletkowego. Przeprowadzono również ocenę nasilenia rdzy żółtej powodowanej przez grzyb $P$. striiformis określając procent powierzchni liści z objawami choroby na wszystkich roślinach na poletku.

\section{Badanie odporności typu I i typu II / Evaluation of resistance of type $I$ and type II}

W Radzikowie przebadano dodatkowo odporność na F. culmorum typu I (odporność na infekcję) oraz typu II (odporność na rozprzestrzenianie się Fusarium w kłosie). Do badań wybrano 23 linie S oraz 6 odmian/linii wzorcowych pszenicy ozimej (tab. 1). Do badań włączono również 3 podatne odmiany pszenicy: Belenus, Slade i Meister oraz wysoko podatną odmianę pszenicy twardej (Triticum durum) - Komnata. Założono dwa identyczne doświadczenia $\mathrm{w}$ dwóch tunelach foliowych wyposażonych w instalację zraszającą. Wysiewano po 20 ziarniaków na pojedynczych rządkach o długości $1 \mathrm{~m}$.

W celu określenia odporności typu I kłosy pszenicy opryskiwane były zawiesiną zarodników F. culmorum, natomiast $\mathrm{w}$ celu określenia odporności typu II zastosowana była metoda inokulacji punktowej kłosów (Góral i wsp. 2015a).

Odporność typu I oceniano stosując metodykę zbliżoną do opisanej przez Kubo i wsp. (2013) oraz metodykę Patton-Ozkurt i wsp. dostępną na stronie US Wheat and Barley Scab Initiative (http://scabusa.org/pdfs/ ptt/cowger type1-screening protocol.pdf). W fazie pełni kwitnienia (BBCH 65) kłosy opryskiwano zawiesiną zarodników 3 izolatów $F$. culmorum o stężeniu $10^{5}$ zarodników $/ \mathrm{ml}$. Zastosowano izolaty wykorzystane w polowych doświadczeniach infekcyjnych: KF 846, ZFR16 i ZFR 112 (Góral i wsp. 2015b). Liczbę punktów infekcji (\#pi) oceniano po 7 dniach od inokulacji na $10 \mathrm{kłosach}$ na poletku, traktując kłosek z nekrozą, jako jeden pi. Po 21 dniach po inokulacji przeprowadzona została dodatkowo ocena indeksu fuzariozy kłosów.

Metodyka oceny odporności typu II była zbliżona do opisanej przez Bai, dostępnej na stronie US Wheat and Barley Scab Initiative (http://scabusa.org/pdfs/ptt/ Bai 
Greenhouse-Screening.pdf). Kłosy inokulowano w fazie pełni kwitnienia (BBCH 65) przez umieszczanie kropli (około $50 \mathrm{mcl}$ ) zawiesiny zarodników $F$. culmorum w środkowym kłosku wybranych kłosów za pomocą samonapełniającej się strzykawki. Stężenie zawiesiny wynosiło $50 \times 103$ zarodników/ml, co dawało około 2500 zarodników na kłosek. Zastosowano dwa izolaty: KF 846 i ZFR112. Każdym izolatem inokulowano po 5 kłosów danej odmiany/linii. Nasilenie fuzariozy kłosów oceniano przez określanie liczby kłosków z objawami choroby - liczba kłosków porażonych (\#pk) 21 dni po inokulacji. Objawy te to nekrozy, bielenie kłosków, a w niektórych przypadkach zarodnikowanie Fusarium w postaci różowo-pomarańczowego nalotu.

\section{Analiza występowania allelu markera molekularnego UMN10 blisko sprzężonego z genem Fhb1 / Anlaysis of presence of the allele of the molecular marker UMN10 close linked to Fhb1 gene}

Materiał roślinny do analiz molekularnych prowadzono w kontrolowanych warunkach komory klimatycznej (16 godzin światła $/ 22^{\circ} \mathrm{C}$ oraz 8 godzin ciemności $/ 18^{\circ} \mathrm{C}$ ). DNA wyizolowano z liści pięciu 2-3 tygodniowych roślin reprezentujących każdy z badanych obiektów, tj. 52 linii S, odmian rodzicielskich (Begra, Korweta, Sumai 3, Turnia) oraz dwóch wzorców 20828 i UNG 136.6.1.1, które miały w rodowodzie odmianę Sumai 3 (tab. 1).

Izolację DNA przeprowadzono przy zastosowaniu zestawu Nucleo Mag 96 (Macherey-Nagel GmbH \& Co. KG, 52355 Düren, Niemcy) ze zmianami (Czembor i wsp. 2014) przy pomocy zautomatyzowanej stacji roboczej Freedom Evo (Tecan Group Ltd., Seestrasse 103, CH-8708 Männedorf, Szwajcaria). Obecność genu Fhbl stwierdzano na podstawie występowania produktu PCR długości 239 pz po amplifikacji locus markera UMN10 sprzężonym z typowanym genem (Liu i wsp. 2008). Mieszanina reakcyjna o objętości $8 \mu \mathrm{l}$ zawierała następujące komponenty: $60 \mathrm{ng}$ matrycy DNA, $1 \mathrm{U}$ Taq polimerazy (Thermo Scientific, Fermentas GmbH, Niemcy), $1 \times$ PCR bufor $\mathrm{z}$ domieszką $\left(\mathrm{NH}_{4}\right)_{2} \mathrm{SO}_{4}$ (Fermentas), 2,5 $\mathrm{mM} \quad \mathrm{MgCl}_{2}$ (Fermentas), $200 \mu \mathrm{M}$ każdego $\mathrm{z}$ deoksynukleotydów (Fermentas) oraz po $0,5 \mu \mathrm{M}$ każdego $\mathrm{z}$ pary starterów (5'-CGTGGTT CCACGTCTTCTTA-3' i 5'-TGAAGTTCATGCCACG CATA-3'). Jeden z pary starterów był znakowany barwnikiem fluorescencyjnym TET $\mathrm{w}$ formie amidofosforynu (ThermoFisher Scientific, Stany Zjednoczone). Amplifikację prowadzono w aparacie Mastercycler ep Gradient (Eppendorf $\mathrm{GmbH}$, Niemcy) według programu: $94^{\circ} \mathrm{C} / 3 \mathrm{~min}$. wstępna denaturacja, 10 cykli składających się z etapów $94^{\circ} \mathrm{C} / 30 \mathrm{~s}, 60^{\circ} \mathrm{C} / 30 \mathrm{~s}$ i $72^{\circ} \mathrm{C} / 1 \mathrm{~min}$. oraz 30 cykli przy obniżonej temperaturze denaturacji do $90^{\circ} \mathrm{C}$, reakcja kończyła się inkubacją $72^{\circ} \mathrm{C} / 5 \mathrm{~min}$.

Rozdział i analizę znakowanych produktów PCR prowadzono przy użyciu analizatora DNA ABI377XL (Applied Biosystems, Foster City, USA) wspomaganego oprogramowaniem GeneScan 3.1 (Applied Biosystems) stosując 4,5\% denaturujący żel poliakrylamidowy (Long Ranger, Cambrex Bio Science, USA). Do nanoszenia mieszaniny poreakcyjnej na żel poliakrylamidowy stosowano grzebienie membranowe (100 zębów) zgodnie z zaleceniem producenta (Web Scientific Ltd., Wielka Brytania).

\section{Analiza statystyczna / Statistical analysis}

Analiza statystyczna została wykonana za pomocą pakietu Microsoft ${ }^{\circledR}$ Excel 2010/XLSTATC-Pro (Version 2015.2.02.18135, Addinsoft, Inc., Brooklyn, NY, USA). Obliczono współczynniki korelacji (XLSTAT: Correlation tests). W celu zgrupowania linii na podstawie odporności na fuzariozę kłosów (średnie $\mathrm{z}$ dwóch lokalizacji) i rdzę żółtą oraz terminu kwitnienia (średnie $\mathrm{z}$ dwóch lokalizacji), wysokości roślin (średnie z dwóch lokalizacji) i plonu ziarna zastosowano metodę analizy składowych głównych (XLSTAT: $P C A$ ). Istotność różnic między grupami linii pod względem IFK, wysokości i plonu ziarna określono za pomocą testu Kruskala-Wallisa (XLSTAT: Non-paratmetric tests - Comparison of $k$ samples). Porównania wielokrotne między grupami przeprowadzono za pomocą testu Steel-Dwass-Critchlow-Fligner. Wariancje populacji (n) obliczono za pomocą modułu XLSTAT: Descriptive statistics.

\section{Wyniki i dyskusja / Results and discussion}

Analiza występowania allelu 239 pz markera molekularnego UMN10 wykazała jego brak u odmian matecznych linii S czyli Begry, Korwety oraz Turni (tab. 2). Występowanie tego allelu zostało natomiast potwierdzone u odmiany ojcowskiej Sumai 3.

Wśród 52 analizowanych linii S u 29 (56\%) stwierdzono obecność produktu PCR o długości 239 pz, czyli posiadały one gen Fhbl (tab. 2). U 20 (39\%) linii stwierdzono obecność produktu PCR o długości 236 pz, czyli nie posiadały one typowanego genu odporności. Trzy linie (S 06, S 23, S 28) okazały się heterogenne, ponieważ analiza DNA roślin tych linii wykazała obecność obydwóch alleli w locus UMN10, tj. produktów PCR 239 pz i 236 pz.

Analiza dwóch linii wzorcowych o wysokiej odporności na fuzariozę kłosów wykazała obecność genu Fhb1 u linii UNG 136.6.1.1 oraz jego brak u linii 20828.

W dwóch doświadczeniach w warunkach kontrolowanych przebadano odporność typu I i typu II u 23 linii S oraz 11 form wzorcowych (tab. 3). Średnia odporność typu I wyniosła 1,5 punktów infekcji (\#pi), zakres zmienności od 1,0 do 2,7 \#pi. Dla linii S było to średnio 1,4 \#pi oraz 1,0-2,0 \#pi. Maksymalna liczba punktów infekcji na pojedynczych kłosach wyniosła 3,0 \#pi. Najwyższą odporność typu I wykazały linie: S 48 [Fhb1+], S 49 [Fhb1+], S 57 [Fhb1+] oraz odmiany wzorcowe: 20828 [Fhb1-] i Slade. Najniższa odporność została stwierdzona u linii: S 40 [Fhb1-], S 39 [Fhb1+], S 15 [Fhb1-] i S 23 [Fhb1+/-] oraz odmian wzorcowych - pszenicy twardej Komnata, odpornej - UNG 136.6.1.1 [Fhb1+] i podatnych: SMH 8816, SMH 8694, Belenus.

Średnia odporność typu II wyniosła 1,4 porażonych kłosków (\#pk), zakres zmienności od 0,6 do 5,3 \#pk (tab. 3). Dla linii $\mathrm{S}$ było to odpowiednio 0,9 oraz 0,7-1,3 \#pk. Najwyższą odporność typu II wykazały linie: S 38 [Fhb1-] i S 45 [Fhb1+] oraz dwa wzorce odporne: A40-19-1-2 i UNG 136.6.1.1 [Fhb1+]. Dla 15 linii S porażenie kłosa wyniosło poniżej 1,0 \#pk. Nekrozy obejmowały plewki w pojedynczych kwiatkach lub całe kwiatki. 
Tabela 2. Występowanie produktów PCR w locus markera UMN10 blisko sprzężonego z genem Fhb1 u 52 linii S, odmian rodzicielskich i wzorców odpornych

Table 2. Presence of the resistance allele at the locus of UMN10 marker linked to Fhb1 gene in 61 'S' lines, parental cultivars and resistant control standards

\begin{tabular}{c|c|c}
\hline $\begin{array}{c}\text { Allel 239 } \mathrm{pz}^{1} \\
\text { Allele 239 } \mathrm{bp}^{1}\end{array}$ & $\begin{array}{c}\text { Allel 236 } \mathrm{pz}^{2} \\
\text { Allele 236 } \mathrm{bp}^{2}\end{array}$ & $\begin{array}{c}\text { Allel 239 pz/allel 236 pz } \\
\text { Allele 239 bp/allele 236 bp }\end{array}$ \\
\hline Sumai 3; & Begra; Korweta; Turnia; & S 06; S 23; S 28 \\
S 01; S 02; S 03; S 04; S 05; S 10; S 11; S 12; & S 07; S 08; S 09; S 14; S 15; S 16; S 18; & \\
S 13; S 26; S 27; S 29; S 30; S 32; S 33; S 39; & S 19; S 20; S 21; S 22; S 24; S 25; S 31; & \\
S 42; S 43; S 44; S 45; S 46; S 48; S 50; S 51; & S 34; S 35; S 37; S 38; S 40; S 41; & 20828 \\
S 52; S 55; S 56; S 57; S 59; & & 23 UNG 136.6.1.1
\end{tabular}

${ }^{1}$ amplifikacja allelu 239 pz w locus markera UMN10 świadczy o występowaniu genu odporności Fhbl, ${ }^{2}$ amplifikacja allelu 236 pz w locus markera UMN10 świadczy o braku występowania genu odporności $F h b 1,{ }^{3}$ linie heterogenne

${ }^{1}$ amplification of allel $239 \mathrm{bp}$ in locus of marker UMN10 indicates the presence of resistance gene $F h b 1,{ }^{2}$ amplification of allel 236 bp in locus of marker UMN10 indicates the absence of resistance gene $F h b 1,{ }^{3}$ heterogenic lines

Tabela 3. Odporność typów I i II na fuzariozę kłosów dla 23 linii S oraz odmian i linii wzorcowych Table 3. Resistance of type I and II to Fusarium head blight for 23 linies ' $\mathrm{S}$ ' and standard cultivars/lines

\begin{tabular}{|c|c|c|c|c|c|}
\hline $\begin{array}{l}\text { Lp. } \\
\text { No. }\end{array}$ & $\begin{array}{l}\text { Linia/odmiana } \\
\text { Line/cultivar }\end{array}$ & $\begin{array}{l}\text { Typ I [\#pi] }{ }^{1} \\
\text { Type I [\#ip] }\end{array}$ & $\begin{array}{l}\text { Typ II [\#pk] } \\
\text { Type II [\#is] }\end{array}$ & $\begin{array}{c}\text { Typ I + II } \\
\text { Type I + II }\end{array}$ & $\begin{array}{c}\text { IFK }[\%]^{3} \\
\operatorname{FHBi}[\%]^{3}\end{array}$ \\
\hline 1 & 2 & 3 & 4 & 5 & 6 \\
\hline 1 & S 48 & 1,0 & 0,8 & 0,9 & 21 \\
\hline 2 & S 49 & 1,0 & 0,8 & 0,9 & 21 \\
\hline 3 & S 45 & 1,1 & 0,7 & 0,9 & 14 \\
\hline 4 & A40-19-1-2 (R) & 1,2 & 0,6 & 0,9 & 16 \\
\hline 5 & S 57 & 1,0 & 0,8 & 0,9 & 16 \\
\hline 6 & S 43 & 1,1 & 0,8 & 0,9 & 32 \\
\hline 7 & S 55 & 1,2 & 0,8 & 1,0 & 16 \\
\hline 8 & S 53 & 1,1 & 0,9 & 1,0 & 16 \\
\hline 9 & 20828 (R) & 1,0 & 1,1 & 1,0 & 24 \\
\hline 10 & S 11 & 1,3 & 0,8 & 1,0 & 24 \\
\hline 11 & S 42 & 1,4 & 0,8 & 1,1 & 32 \\
\hline 12 & S 38 & 1,5 & 0,7 & 1,1 & 32 \\
\hline 13 & S 44 & 1,3 & 0,9 & 1,1 & 28 \\
\hline 14 & S 32 & 1,4 & 0,9 & 1,2 & 24 \\
\hline 15 & S 04 & 1,4 & 1,0 & 1,2 & 32 \\
\hline 16 & S 05 & 1,2 & 1,2 & 1,2 & 24 \\
\hline 17 & S 50 & 1,6 & 0,8 & 1,2 & 32 \\
\hline 18 & S 52 & 1,1 & 1,3 & 1,2 & 28 \\
\hline 19 & S 47 & 1,5 & 1,0 & 1,2 & 28 \\
\hline 20 & Turnia & 1,1 & 1,2 & 1,2 & 54 \\
\hline 21 & S 46 & 1,6 & 0,9 & 1,3 & 32 \\
\hline 22 & Arina $(\mathrm{R})$ & 1,2 & 1,3 & 1,3 & 32 \\
\hline 23 & UNG 136.6.1.1 (R) & 1,9 & 0,7 & 1,3 & 28 \\
\hline 24 & S 39 & 1,8 & 0,9 & 1,3 & 40 \\
\hline 25 & S 30 & 1,5 & 1,2 & 1,4 & 32 \\
\hline 26 & S 40 & 1,7 & 1,0 & 1,4 & 56 \\
\hline 27 & S 23 & 2,0 & 0,8 & 1,4 & 32 \\
\hline 28 & S 15 & 1,9 & 1,2 & 1,6 & 48 \\
\hline 29 & SMH 8816 (S) & 2,3 & 2,1 & 2,2 & 90 \\
\hline
\end{tabular}




\begin{tabular}{c|c|c|c|c|c}
\hline 1 & 2 & 3 & 4 & 5 & 6 \\
\hline 30 & Slade & 1,0 & 3,8 & 2,4 & 72 \\
\hline 32 & SMH 8694 (S) & 2,4 & 2,5 & 2,5 & 90 \\
\hline 32 & Belenus & 2,7 & 2,2 & 2,5 & 100 \\
\hline 33 & Meister & 1,3 & 5,3 & 3,3 & 64 \\
\hline 34 & Komnata (T. durum) & 1,7 & 5,0 & 3,4 & 100 \\
\hline \multicolumn{2}{l|}{ Średnia dla linii - Means for lines } & 1,4 & 0,9 & 1,2 & 28,7 \\
\hline \multicolumn{2}{l}{ Średnia - Mean } & 1,5 & 1,4 & & 1,4 \\
\hline
\end{tabular}

${ }^{1}$ liczba punktów infekcji (\#pi), ${ }^{2}$ liczba porażonych kłosków (\#pk), ${ }^{3}$ indeks fuzariozy kłosów w warunkach prowokacyjnych

${ }^{1}$ number of infection points (\#ip), ${ }^{2}$ number of infected spikelets (\#is), ${ }^{3}$ Fusarium head blight index under provocative conditions

Taki stopień porażenia był oceniany jako 0,5 \#pk. Najniższa odporność została stwierdzona u wzorców podatnych SMH 8816 i SMH 8694 oraz odmian: Belenus, Slade, Komnata (T. durum) i Meister. Spośród linii S najniższą odporność typu II posiadały - S 05 [Fhb1+], S 30 [Fhb1+], S 15 [Fhb1-] is 52 [Fhb1+].

Najwyższą średnią odporność obu typów wykazały linie: S 43, S 45, S 48, S 49 i S 57 (wszystkie posiadające gen $F h b 1$ ) oraz wzorzec odporny - A40-19-1-2. Najniższą średnią odpornością charakteryzowały się wzorce podatne - SMH 8816 i SMH 8694 oraz odmiany: Slade, Belenus, Meister, Komnata (T. durum). Spośród linii S najniższą średnią odporność obu typów posiadały - S 40 [Fhb1-], S 23 [Fhb1+/-], S 30 [Fhb1+] i S 15 [Fhb1-].

Indeks fuzariozy kłosów w warunkach kontrolowanych wyniósł 39,1\%, zakres zmienności cechy 14,0-100\%. Najsłabiej porażone były kłosy linii: S 45, S 57, S 55, S 53 (wszystkie posiadające gen $F h b 1$ ) oraz wzorca odpornego - A40-19-1-2. Najsilniej porażone były formy podatne: SMH 8816, SMH 8694 oraz odmiana Belenus i pszenica twarda Komnata. Wśród linii $\mathrm{S}$ najsilniej porażone były kłosy linii nieposiadających genu Fhb1 - S 15 i S 40.

Brak było korelacji obu typów odporności $(\mathrm{r}=0,246)$. Odporności typu I i II korelowały istotnie $(\mathrm{p}<0,001)$ $\mathrm{z}$ IFK w warunkach kontrolowanych - odpowiednio $\mathrm{r}=0,634$ i $\mathrm{r}=0,790$. Najwyższe wartości przyjmował współczynnik korelacji IFK ze średnią odpornością obu typów $(\mathrm{r}=0,888)$.

Linie $\mathrm{S}$ wysoko odporne $\mathrm{w}$ warunkach polowych wykazały odporność typu I zbliżoną do podatnych odmian: Slade, Meister lub Komnata. Można to thumaczyć mechanizmem działania genu Fhb1. Stwierdzono, że ekspresja genu $F h b 1$ zachodzi w późniejszym etapie infekcji kłosa przez Fusarium (maksimum po 7 dniach ) (Kosaka i wsp. 2015). Efektem tego jest tworzenie się nekroz na kłoskach w kłosie odmiany Sumai 3 lub odmian pokrewnych inokulowanych przez opryskiwanie zawiesiną Fusarium $\mathrm{w}$ warunkach prowokacyjnych. Uruchomienie mechanizmów odpornościowych powoduje jednakże zahamowanie rozprzestrzeniania się grzyba na kolejne kłoski. Stąd obserwowana względnie niska odporność na infekcję (typ I) niektórych linii S lub wzorca UNG 136.6.1.1. Wysoka odporność typu II tych genotypów dała w efekcie niską podatność na fuzariozę kłosów w warunkach polowych. Należy pamiętać, że ocena odporności typu I jest trudna ze względu na wpływ czynników, które modyfikują uzyskiwane wyniki. Takim czynnikiem jest typ kwitnienia zbóż - otwarty, zamknięty lub mieszany (Kubo i wsp. 2010; Skinnes i wsp. 2010; Lu i wsp. 2013). Najsłabiej porażane są genotypy o typie zamkniętym, natomiast najsilniej genotypy o mieszanym typie kwitnienia (Kubo i wsp. 2013).

Linie S wykazały małą podatność na fuzariozę kłosów w warunkach polowych (tab. 4). Średni IFK wyniósł 3,4\%. Zakres zmienności cechy mieścił się $\mathrm{w}$ granicach 1,0 $6,0 \%$. Najwyższą odpornością charakteryzowało się 5 linii uzyskanych $\mathrm{z}$ mieszańca Turnia $\times$ Sumai 3 . Linie te zawierały gen $F h b 1$. Wysoko odporne były również linie, u których nie stwierdzono obecności genu Fhbl, takie jak np. S 31, S 38, S 08. Najwyższą podatność wykazało 5 linii. Jedna z tych linii - S 26 - posiadała gen Fhbl, natomiast u pozostałych obecności genu nie stwierdzono. Odporność 30 linii była wyższa niż odporność wzorca UNG 136.6.1.1 zawierającego gen Fhb1. Wyższą odporność w warunkach polowych wykazał wzorzec 20828, który nie posiadał genu Fhb1. Indeks fuzariozy kłosów dla 23 linii S był niższy niż obserwowany dla tego wzorca.

Indeks fuzariozy kłosów dla linii posiadających gen Fhb1 wyniósł $2,9 \%$, natomiast dla linii bez tego genu 4,0\%. Różnica między grupami była istotna statystycznie. Zmienność IFK w obu grupach była zbliżona. Wariancja cechy wyniosła odpowiednio 1,167 i 1,248. Trzy grupy linii w zależności od odmiany matecznej charakteryzowały się podobnym średnim IFK. Dla odmiany Begra było to $3,3 \%$, dla odmiany Korweta $-3,6 \%$ oraz dla odmiany Turnia $-3,2 \%$. Różnice między grupami były nieistotne. Największą zmienność IFK odnotowano dla linii uzyskanych z odmiany Turnia (wariancja 2,185), najniższą dla linii uzyskanych z odmiany Begra (wariancja 0,212).

Linie posiadające gen Fhbl wykazywały niższą podatność w porównaniu do linii nieposiadających tego genu. W obu grupach wystąpiła jednakże zmienność reakcji i zidentyfikowano linie o wysokiej odporności przewyższającej formy wzorcowe. W przypadku pierwszej grupy był to efekt ekspresji genu Fhb1. W przypadku drugiej grupy mogła nastąpić kumulacja innych genów/loci odporności występujących u odmiany Sumai 3 (Buerstmayr i wsp. 2009). Udział w zwiększaniu odporności mogły mieć również loci odporności o niskim efekcie obecne u odmian matecznych. Występowanie takich loci w europejskiej puli genetycznej pszenicy ozimej zostało już stwierdzone (Miedaner i wsp. 2011; Kollers i wsp. 2013). 
Tabela 4. Termin pełni kwitnienia, wysokość roślin, plon ziarna z poletka oraz indeksy fuzariozy kłosów (IFK) dla 52 linii pszenicy ozimej badanych w doświadczeniach infekcyjnych w Radzikowie i Poznaniu (Cerekwica) w roku 2015

Table 4. Full flowering time, plant height, grain yield and Fusarium head blight index (FHBi) for 52 lines of winter wheat evaluated in field experiments in Radzików and Cerekwica (Poznań) in 2015

\begin{tabular}{|c|c|c|c|c|c|c|c|}
\hline $\begin{array}{l}\text { Lp. } \\
\text { No. }\end{array}$ & $\begin{array}{l}\text { Linia/odmiana } \\
\text { Line/cultivar }\end{array}$ & $\begin{array}{l}\text { Kłos }^{1} \\
\text { Spike }^{1}\end{array}$ & $\begin{array}{l}\text { Kwitnienie [dni] } \\
\text { Flowering time } \\
\text { [Julian days] }\end{array}$ & $\begin{array}{c}\text { Wysokość roślin } \\
\text { Plant height } \\
{[\mathrm{cm}]}\end{array}$ & $\begin{array}{c}\text { Plon ziarna }^{2} \\
\text { Grain yield }^{2} \\
{[\mathrm{~kg}]}\end{array}$ & $\begin{array}{c}\text { IFK } \\
\text { FHBi } \\
{[\%]}\end{array}$ & $\begin{array}{c}\text { Rdza żółta }^{2} \\
\text { Yellow rust }^{2} \\
{[\%]}\end{array}$ \\
\hline 1 & 2 & 3 & 4 & 5 & 6 & 7 & 8 \\
\hline 1 & S 55 & $\mathrm{O}$ & 158 & 118,7 & 0,673 & 1,0 & 0 \\
\hline 2 & S 45 & $\mathrm{O}$ & 158 & 120,3 & 0,741 & 1,3 & 5 \\
\hline 3 & S 46 & $\mathrm{O}$ & 158 & 120,0 & 0,536 & 1,3 & 5 \\
\hline 4 & S 48 & $\mathrm{O}$ & 159 & 117,7 & 0,538 & 1,5 & 0 \\
\hline 5 & S 44 & $\mathrm{O}$ & 157 & 110,3 & 0,699 & 1,7 & 5 \\
\hline 6 & S 52 & $\mathrm{O}$ & 158 & 124,7 & 0,722 & 2,2 & 5 \\
\hline 7 & S 31 & B & 157 & 107,0 & 0,784 & 2,2 & 0 \\
\hline 8 & S 38 & $\mathrm{O}$ & 158 & 116,0 & 0,727 & 2,3 & 0 \\
\hline 9 & S 10 & $\mathrm{O}$ & 156 & 106,3 & 0,745 & 2,3 & 0 \\
\hline 10 & S 50 & $\mathrm{O}$ & 158 & 117,7 & 0,648 & 2,3 & 5 \\
\hline 11 & S 59 & $\mathrm{O}$ & 157 & 122,0 & 0,442 & 2,5 & 20 \\
\hline 12 & S 08 & B & 156 & 96,7 & 0,594 & 2,5 & 0 \\
\hline 13 & S 28 & $\mathrm{O}$ & 156 & 114,3 & 1,097 & 2,5 & 0 \\
\hline 14 & S 01 & $\mathrm{~B}$ & 158 & 126,7 & 0,460 & 2,5 & 5 \\
\hline 15 & S 13 & $\mathrm{O}$ & 156 & 91,7 & 0,623 & 2,5 & 0 \\
\hline 16 & S 32 & B & 156 & 114,3 & 0,990 & 2,6 & 0 \\
\hline 17 & S 56 & $\mathrm{~B}$ & 158 & 123,3 & 0,562 & 2,8 & 0 \\
\hline 18 & S 09 & $\mathrm{~B}$ & 156 & 110,3 & 0,834 & 2,8 & 5 \\
\hline 19 & S 29 & $\mathrm{O}$ & 157 & 108,7 & 1,081 & 2,8 & 0 \\
\hline 20 & S 39 & $\mathrm{~B}$ & 159 & 119,3 & 0,520 & 2,8 & 5 \\
\hline 21 & S 51 & $\mathrm{O}$ & 157 & 121,0 & 0,647 & 2,8 & 0 \\
\hline 22 & $\mathrm{~S} 02$ & $\mathrm{~B}$ & 158 & 126,0 & 0,461 & 3,0 & 10 \\
\hline 23 & S 23 & $\mathrm{~B}$ & 155 & 116,3 & 0,819 & 3,0 & 0 \\
\hline 24 & S 11 & $\mathrm{O}$ & 156 & 102,3 & 0,828 & 3,0 & 0 \\
\hline 25 & S 03 & $\mathrm{~B}$ & 157 & 125,0 & 0,520 & 3,1 & 10 \\
\hline 26 & S 25 & B & 156 & 115,3 & 0,869 & 3,1 & 0 \\
\hline 27 & $20828(\mathrm{R})$ & $\mathrm{O}$ & 156 & 114,0 & - & 3,1 & 10 \\
\hline 28 & S 12 & $\mathrm{O}$ & 156 & 100,3 & 0,750 & 3,1 & 0 \\
\hline 29 & S 04 & $\mathrm{~B}$ & 157 & 124,7 & 0,416 & 3,3 & 10 \\
\hline 30 & S 24 & $\mathrm{~B}$ & 155 & 122,0 & 1,084 & 3,3 & 0 \\
\hline 31 & S 19 & $\mathrm{O}$ & 156 & 107,0 & 0,719 & 3,5 & 0 \\
\hline 32 & S 05 & $\mathrm{~B}$ & 157 & 122,0 & 0,510 & 3,6 & 20 \\
\hline 33 & UNG 136.6.1.1 (R) & $\mathrm{O}$ & 156 & 120,3 & - & 3,6 & 0 \\
\hline 34 & S 57 & $\mathrm{~B}$ & 158 & 125,3 & 0,637 & 3,7 & 0 \\
\hline 35 & S 30 & $\mathrm{O}$ & 157 & 110,3 & 1,125 & 3,7 & 0 \\
\hline 36 & S 06 & $\mathrm{~B}$ & 157 & 116,7 & 0,643 & 3,8 & 5 \\
\hline 37 & Fregata (R) & $\mathrm{B}$ & 160 & 105,0 & - & 3,8 & 5 \\
\hline 38 & S 07 & $\mathrm{~B}$ & 156 & 117,3 & 0,749 & 3,8 & 5 \\
\hline 39 & S 16 & $\mathrm{O}$ & 156 & 111,3 & 0,771 & 4,0 & 0 \\
\hline 40 & S 15 & $\mathrm{O}$ & 157 & 110,0 & 0,713 & 4,1 & 0 \\
\hline 41 & S 27 & $\mathrm{O}$ & 156 & 117,3 & 0,917 & 4,1 & 0 \\
\hline 42 & S 20 & $\mathrm{O}$ & 156 & 106,7 & 0,692 & 4,2 & 0 \\
\hline 43 & S 18 & $\mathrm{O}$ & 156 & 111,7 & 0,830 & 4,3 & 0 \\
\hline
\end{tabular}




\begin{tabular}{|c|c|c|c|c|c|c|c|}
\hline 1 & 2 & 3 & 4 & 5 & 6 & 7 & 8 \\
\hline 44 & S 37 & $\mathrm{O}$ & 157 & 99,3 & 0,567 & 4,3 & 0 \\
\hline 45 & S 14 & $\mathrm{O}$ & 157 & 106,7 & 0,752 & 4,5 & 0 \\
\hline 46 & A40-19-1-2 (R) & $\mathrm{O}$ & 161 & 104,3 & - & 4,5 & 0 \\
\hline 47 & S 21 & $\mathrm{O}$ & 157 & 118,3 & 0,973 & 4,7 & 0 \\
\hline 48 & S 43 & $\mathrm{O}$ & 158 & 108,3 & 0,370 & 4,7 & 20 \\
\hline 49 & S 35 & $\mathrm{O}$ & 157 & 111,7 & 0,799 & 4,7 & 5 \\
\hline 50 & S 42 & $\mathrm{O}$ & 159 & 109,7 & 0,465 & 4,8 & 5 \\
\hline 51 & S 33 & B & 156 & 123,7 & 1,071 & 4,9 & 0 \\
\hline 52 & S 40 & B & 158 & 112,3 & 0,657 & 5,0 & 20 \\
\hline 53 & S 26 & $\mathrm{O}$ & 157 & 113,7 & 1,079 & 5,2 & 0 \\
\hline 54 & S 41 & B & 157 & 118,3 & 0,607 & 5,6 & 0 \\
\hline 55 & S 22 & $\mathrm{O}$ & 156 & 110,3 & 0,975 & 5,8 & 0 \\
\hline 56 & S 34 & $\mathrm{O}$ & 157 & 112,0 & 0,828 & 6,0 & 0 \\
\hline 57 & Arina (R) & $\mathrm{B}$ & 157 & 115,0 & - & 6,5 & 0 \\
\hline 58 & Tonacja & B & 158 & 106,9 & 1,102 & 9,5 & 5 \\
\hline 59 & SMH 8694 (S) & B & 157 & 84,0 & - & 21,5 & 0 \\
\hline 60 & SMH 8816 (S) & B & 157 & 86,0 & - & 21,9 & 0 \\
\hline \multicolumn{2}{|c|}{$\begin{array}{l}\text { Średnie dla linii } \\
\text { Means for lines }\end{array}$} & & 156,9 & 114,2 & 0,728 & 3,4 & 3,3 \\
\hline
\end{tabular}

$\mathrm{R}$ - wzorce odporne, $\mathrm{S}$ - wzorce podatne, ${ }^{1} \mathrm{O}$ - ościsty, B - bezostny, ${ }^{2}$ wyniki z Radzikowa

$\mathrm{R}$ - resistant checks, $\mathrm{S}$ - susceptible checks, ${ }^{1} \mathrm{O}$ - awned, B - awnless, ${ }^{2}$ results from Radzików

Linie S charakteryzowały się dość dużą wysokością roślin wynoszącą średnio $114,2 \mathrm{~cm}$ (zakres zmienności 91,7-126,7 cm) (tab. 4). Jedynie 3 linie (S 08, S 13, S 37) były niższe niż $100 \mathrm{~cm}$. Osiem linii było niższych od odmiany Fregata, natomiast 11 niższych od odmiany Tonacja. Średnia wysokość linii z genem Fhbl wyniosła $116,3 \mathrm{~cm}$, natomiast bez genu $-111,0 \mathrm{~cm}$. Różnica między grupami była istotna statystycznie. Zakres zmienności w pierwszej grupie wynosił $91,7-126,7 \mathrm{~cm}$, a w drugiej było to $96,7-122,0 \mathrm{~cm}$. Połowa linii w pierwszej grupie miała wysokość powyżej $118,7 \mathrm{~cm}$, dla drugiej grupy było to jedynie $111,5 \mathrm{~cm}$. Dla 53 odmian pszenicy znajdujących się w rejestrze Centralnego Ośrodka Badania Odmian Roślin Uprawnych średnia wysokość w tych samych warunkach wyniosła $98,6 \mathrm{~cm}$.

Trzy grupy linii w zależności od odmiany matecznej charakteryzowały się zróżnicowaną wysokością. Dla odmiany Begra było to $122,6 \mathrm{~cm}$, dla odmiany Korweta $109,4 \mathrm{~cm}$ oraz dla odmiany Turnia $-116,0 \mathrm{~cm}$. Różnice między grupami były istotne statystycznie. Największą zmienność wysokości odnotowano dla linii uzyskanych z krzyżowania z odmianami Korweta i Turnia (wariancja odpowiednio 53,885 i 42,289), a najniższą dla linii uzyskanych z krzyżowania z odmianą Begra (wariancja 16,905).

Plon ziarna był zróżnicowany i wynosił średnio $0,728 \mathrm{~kg}$ (tab. 4). Wartość cechy wahała się w granicach $0,370-1,125 \mathrm{~kg}$. Najniższy plon ziarna (poniżej $0,5 \mathrm{~kg}$ ) zanotowano u 6 linii uzyskanych z mieszańców Begra $\times$ Sumai 3 i Turnia $\times$ Sumai 3, posiadających gen Fhbl. Najwyższy plon ziarna (powyżej $1 \mathrm{~kg}$ ) stwierdzono u 6 linii uzyskanych z mieszańców Korweta $\times$ Sumai 3 i Turnia $\times$ Sumai 3 . Plon ten był zbliżony do plonu dla odmiany Tonacja $(1,102 \mathrm{~kg})$.

Średni plon ziarna linii $\mathrm{z}$ genem $F$ hbl wyniósł $0,682 \mathrm{~kg}$, natomiast bez genu $-0,776 \mathrm{~kg}$. Różnica między grupami była istotna statystycznie. Zakres zmienności w pierwszej grupie wynosił $0,370-1,125 \mathrm{~kg}$, w drugiej było to $0,567-1,084 \mathrm{~kg}$. Zmienność plonu była wyższa w grupie linii z genem $F h b 1$. Wariancja cechy wyniosła odpowiednio 0,049 i 0,017 .

Trzy grupy linii w zależności od odmiany matecznej charakteryzowały się zróżnicowanym plonem ziarna. Dla odmiany Begra było to $0,531 \mathrm{~kg}$, dla odmiany Korweta $0,845 \mathrm{~kg}$ oraz dla odmiany Turnia $-0,681 \mathrm{~kg}$. Różnica plonu między liniami uzyskanymi z odmiany Korweta a pozostałymi była istotna statystycznie. Największą zmienność plonu odnotowano dla linii uzyskanych z odmian Turnia i Korweta (wariancja odpowiednio 0,035 i 0,024$)$, a najniższą dla linii uzyskanych z odmiany Begra (wariancja 0,014 ).

Podatność na rdzę żółtą zaobserwowano u 19 linii, $\mathrm{w}$ tym wszystkich linii (7) uzyskanych z krzyżowania z odmianą Begra (tab. 4). W przypadku linii uzyskanych $\mathrm{z}$ krzyżowania $\mathrm{z}$ odmianą Korweta małe nasilenie rdzy żółtej obserwowano u jednej linii. Najwyższa była podatność 4 linii - S 05, S 40, S 43, S 59. Występowanie rdzy żółtej na liściach miało istotny, negatywny wpływ na plon ziarna. Współczynnik korelacji obu cech wynosił $\mathrm{r}=-0,624$.

Średni termin pełni kwitnienia linii $\mathrm{S}$ w dwóch lokalizacjach wynosił 156,9 dnia (tab. 4). Rozpiętość terminu kwitnienia wynosiła 4 dni. Najwcześniejsze były linie: S 23 i S 24 (155 dni), najpóźniejsze to linie: S 39, S 42 


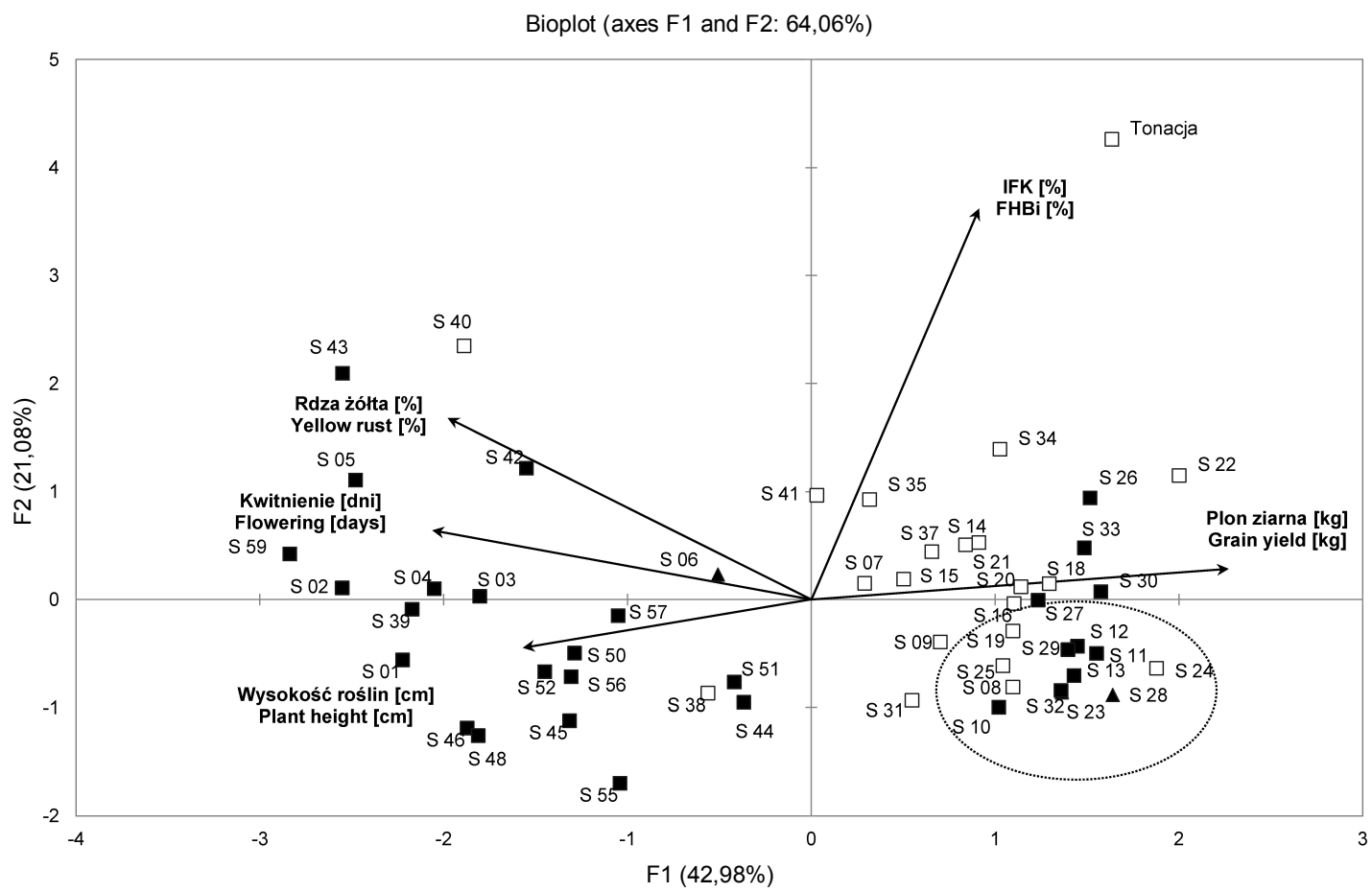

Rys. 1. Układ współrzędnych dwóch składowych głównych dla 52 linii S pszenicy ozimej oraz odmiany Tonacja. Składowe wyjaśniają $64,06 \%$ zmienności terminu kwitnienia, wysokości roślin, plonu ziarna, odporności na fuzariozę kłosów (IFK) oraz odporności na rdzę żółtą (patrz tab. 4). Okręgiem oznaczono linie kumulujące wszystkie korzystne cechy

- - linie zawierajace gen Fhbl, $\square$ - linie bez genu Fhbl, $\mathbf{\Delta}$ - linie heterogenne

Fig. 1. Biplot of the principal component analysis for 52 winter wheat lines ' $\mathrm{S}$ ' and cultivar Tonacja. Two first components explained $64.06 \%$ of variability of flowering time, plant height, grain yield, FHB index (FHBi) and yellow rust resistance (Tab. 4). Lines combining all positive characters marked with circle

- lines containing Fhbl gene, $\square-$ lines without Fhbl gene, $\mathbf{\Delta}$ - heterogenic lines

i S 48 (159 dni). Średni termin kwitnienia linii z genem Fhbl wyniósł 157,3 dni, natomiast bez genu $-156,6 \mathrm{~cm}$. Różnica między grupami była istotna statystycznie. Trzy grupy linii w zależności od odmiany matecznej charakteryzowały się zróżnicowanym terminem kwitnienia. Dla odmiany Begra było to 157,0 dni, dla odmiany Korweta 156,3 dnia oraz dla odmiany Turnia - 157,5 dnia. Różnice między liniami uzyskanymi z krzyżowania z odmianami Korweta i Turnia były istotne statystycznie. Późniejszy termin kwitnienia negatywnie wpływał na plon ziarna linii. Współczynnik korelacji cech wyniósł $\mathrm{r}=-0,565$.

Linie uzyskane z krzyżowania bezostnych polskich odmian z ościstą odmianą Sumai 3 miały oba typy kłosa. Większość linii (32) miała kłos ościsty, natomiast kłos bezostny miało 20 linii (w tym wszystkie linie z mieszańca Begra $\times$ Sumai 3). Nie znaleziono zależności między obecnością genu Fhb1 a ościstością kłosa.

Za pomocą analizy składowych głównych stwierdzono, że część linii $\mathrm{S}$ łączyła korzystne cechy, takie jak: odporność na fuzariozę kłosów, odporność na rdzę żółtą, wysoki plon ziarna, wczesność oraz wysokość roślin na poziomie odmiany Tonacja (rys. 1). Były to linie: nieposiadające genu Fhbl - S 08, S 16, S 19, S 24, S 25; posiadające gen $F h b 1$ - S 10, S 11, S 12, S 13, S 27, S 29, S 30, S 32 i linie heterogenne - S 23, S 28. Wyniki te pokazują, że jest możliwe uzyskanie drogą selekcji segregantów o wysokiej odporności i korzystnych cechach agronomicznych. Linie takie zawierają gen(y) odporności wprowadzone ze źródeł odporności (np. Fhbl), ale równocześnie identyfikowane są linie odporne pozbawione tych genów. W pracy Clark i wsp. (2016) stwierdzono, że na 43 linie o wysokiej odporności na fuzariozę kłosów i akumulację DON 6 linii nie posiadało żadnego z 2 wprowadzanych genów odporności (Fhbl, QFhs.nau-2DL), natomiast pozostałe posiadały obydwa lub pojedyncze geny. Badania odmian i materiałów hodowlanych pszenicy ozimej w Stanach Zjednoczonych pozwoliły na zidentyfikowanie około 5\% genotypów wysoko odpornych na fuzariozę kłosów nieposiadających genu Fhbl (Jin i wsp. 2013). Autorzy obserwowali również genotypy posiadające gen $F h b 1$ wykazujące podatność na fuzariozę kłosów, co wskazuje na różną ekspresję genu w różnych podłożach genetycznych i konieczność stosowania selekcji fenotypowej równocześnie z selekcją molekularną.

\section{Wnioski / Conclusions}

1. Obecność genu Fhbl stwierdzono u 56\% badanych linii za pomocą markera molekularnego UMN10 blisko sprzężonego z tym genem.

2. Badane linie miały średnio wysoką odporność typu II (pojedyncza plewka lub jeden kłosek z objawami nekrozy - brak rozprzestrzeniania się patogena), natomiast wystąpiło zróżnicowanie odporności typu I (od 1 do 3 punktów infekcji). 
3. Linie posiadające gen odporności Fhbl miały średnio wyższą odporność na grzyb $F$. culmorum powodujący fuzariozę kłosów, większą wysokość roślin oraz niższy plon ziarna $\mathrm{w}$ porównaniu do linii pozbawionych tego genu.
4. W obu grupach linii (linie $\mathrm{z}$ genem i bez genu Fhbl) zidentyfikowano formy o bardzo wysokiej odporności, małej wysokości roślin oraz wysokim plonie ziarna.

\section{Literatura / References}

Anderson J.A., Chao S., Liu S. 2007. Molecular breeding using a major QTL for Fusarium head blight resistance in wheat. Crop Science 47: S112-S119.

Anderson J.A., Wiersma J.J., Linkert G.L., Reynolds S., Kolmer J.A., Jin Y., Dill-Macky R., Hareland G.A. 2015. Registration of 'Rollag' spring wheat. Journal of Plant Registrations 9 (2): 201-207.

Bai G.H., Shaner G., Ohm H. 2000. Inheritance of resistance to Fusarium graminearum in wheat. Theoretical and Applied Genetics 100: $1-8$

Bottalico A., Perrone G. 2002. Toxigenic Fusarium species and mycotoxins associated with head blight in small-grain cereals in Europe. European Journal of Plant Pathology 108: 611-624.

Boutigny A.-L., Richard-Forget F., Barreau C. 2008. Natural mechanisms for cereal resistance to the accumulation of Fusarium trichothecenes. European Journal of Plant Pathology 121: 411-423.

Buerstmayr H., Ban T., Anderson J.A. 2009. QTL mapping and marker-assisted selection for Fusarium head blight resistance in wheat: A review. Plant Breeding 128: 1-26.

Buerstmayr H., Lemmens M., Berlakovich S., Ruckenbauer P. 1999. Combining ability of resistance to head blight caused by Fusarium culmorum (W.G. Smith) in the $\mathrm{F}_{1}$ of a seven parent diallel of winter wheat (Triticum aestivum L.). Euphytica 110: 199-206.

Buerstmayr H., Lemmens M., Hartl L., Doldi L., Steiner B., Stierschneider M., Ruckenbauer P. 2002. Molecular mapping of QTLs for Fusarium head blight resistance in spring wheat. I. Resistance to fungal spread (type II resistance). Theoretical and Applied Genetics 104: 84-91.

Buerstmayr H., Lemmens M., Schmolke M., Zimmermann G., Hartl L., Mascher F., Trottet M., Gosman N.E., Nicholson P. 2008. Multi-environment evaluation of level and stability of FHB resistance among parental lines and selected offspring derived from several European winter wheat mapping populations. Plant Breeding 127: 325-332.

Clark A.J., Sarti-Dvorjak D., Brown-Guedira G., Dong Y., Baik B., Van Sanford D.A. 2016. Identifying rare FHB-resistant segregants in intransigent backcross and $\mathrm{F}_{2}$ winter wheat populations. Frontiers in Microbiology 7: 1-14.

Czembor P.C., Sejbuk K., Kleszcz R. 2014. Evaluation of a partially-automated magnetic bead-based method for DNA extraction for wheat and barley MAS. Cereal Research Communications 42: 27-37.

Czembor P.C., Słowacki P. 2014. Marker assisted backcrossing for Fusarium head blight resistance and high grain protein content in winter wheat. p. 251. Cereals for Food, Feed and Fuel - Challenge for Global Improvement; Joint EUCARPIA Cereal Section \& $\mathrm{I} \cdot \mathrm{T} \cdot \mathrm{M} \cdot \mathrm{I}$ Conference. Germany, Wernigerode, 29.06-04.07.2014, $359 \mathrm{pp}$.

Foroud N.A., Eudes F. 2009. Trichothecenes in cereal grains. International Journal of Molecular Sciences 10: 147-173.

Góral T., Walentyn-Góral D., Wiśniewska H. 2015a. Odporność typu I i II pszenicy i pszenżyta na fuzariozę kłosów. [Fusarium head blight resistance of types I and II in wheat and triticale]. Biuletyn Instytutu Hodowli i Aklimatyzacji Roślin 277: 33-45.

Góral T., Ochodzki P., Walentyn-Góral D., Belter J., Majka M., Kwiatek M., Wiśniewska H., Bogacki J., Drzazga T., Ługowska B., Matysik P., Witkowski E., Rubrycki K., Woźna-Pawlak U. 2015b. Odporność genotypów pszenicy ozimej na fuzariozę kłosów i akumulację toksyn fuzaryjnych w ziarnie scharakteryzowana za pomocą różnych typów odporności. [Resistance of winter wheat lines to Fusarium head blight and Fusarium toxins accumulation characterized using different types of resistance]. Biuletyn Instytutu Hodowli i Aklimatyzacji Roślin 276: 19-37.

Jin F., Zhang D., Bockus W., Baenziger P.S., Carver B., Bai G. 2013. Fusarium head blight resistance in U.S. winter wheat cultivars and elite breeding lines. Crop Science 53: 2006-2013.

Kluger B., Bueschl C., Lemmens M., Michlmayr H., Malachova A., Koutnik A., Maloku I., Berthiller F., Adam G., Krska R., Schuhmacher R. 2015. Biotransformation of the mycotoxin deoxynivalenol in Fusarium resistant and susceptible near isogenic wheat lines. PloS ONE 10: e0119656.

Kollers S., Rodemann B., Ling J., Korzun V., Ebmeyer E., Argillier O., Hinze M., Plieske J., Kulosa D., Ganal M.W., Röder M.S. 2013. Whole genome association mapping of Fusarium head blight resistance in European winter wheat (Triticum aestivum L.). PloS ONE 8: e57500.

Kosaka A., Manickavelu A., Kajihara D., Nakagawa H., Ban T. 2015. Altered gene expression profiles of wheat genotypes against Fusarium head blight. Toxins 7: 604-620.

Kubo K., Fujita M., Kawada N., Nakajima T., Nakamura K., Maejima H., Ushiyama T., Hatta K., Matsunaka H. 2013. Minor differences in anther extrusion affect resistance to Fusarium head blight in wheat. Journal of Phytopathology 161: 308-314.

Kubo K., Kawada N., Fujita M., Hatta K., Oda S., Nakajima T. 2010. Effect of cleistogamy on Fusarium head blight resistance in wheat. Breeding Science 60: 405-411.

Lemmens M., Scholz U., Berthiller F., Dall’Asta C., Koutnik A., Schuhmacher R., Adam G., Buerstmayr H., Mesterházy A., Krska R., Ruckenbauer P. 2005. The ability to detoxify the mycotoxin deoxynivalenol colocalizes with a major quantitative trait locus for Fusarium head blight resistance in wheat. Molecular Plant-Microbe Interactions 18: 1318-1324.

Liu S.X., Pumphrey M.O., Gill B.S., Trick H.N., Zhang J.X., Dolezel J., Chalhoub B., Anderson J.A. 2008. Toward positional cloning of Fhb1, a major QTL for Fusarium head blight resistance in wheat. Cereal Research Communications 36: 195-201.

Lu Q., Lillemo M., Skinnes H., He X., Shi J., Ji F., Dong Y., Bjørnstad A. 2013. Anther extrusion and plant height are associated with Type I resistance to Fusarium head blight in bread wheat line „Shanghai-3/Catbird”. Theoretical and Applied Genetics 126: $317-334$. 
Mesterházy Á. 1995. Types and components of resistance to Fusarium head blight of wheat. Plant Breeding 114: 377-386.

Mesterhazy A., Bartok T., Mirocha C.G., Komoroczy R. 1999. Nature of wheat resistance to Fusarium head blight and the role of deoxynivalenol for breeding. Plant Breeding 118: 97-110.

Mesterházy A., Tóth B., Bartók T., Varga M. 2008. Breeding strategies against FHB in winter wheat and their relation to type I resistance. Cereal Research Communications 36: 37-43.

Miedaner T., Würschum T., Maurer H.P., Korzun V., Ebmeyer E., Reif J.C. 2011. Association mapping for Fusarium head blight resistance in European soft winter wheat. Molecular Breeding 28: 647-655.

Schroeder H.W., Christensen J.J. 1963. Factors affecting resistance of wheat to scab caused by Gibberella zeae. Phytopathology 53: 831-838

Skinnes H., Semagn K., Tarkegne Y., Marøy A.G., Bjørnstad Å. 2010. The inheritance of anther extrusion in hexaploid wheat and its relationship to Fusarium head blight resistance and deoxynivalenol content. Plant Breeding 129: 149-155.

Snijders C.H.A. 2004. Resistance in wheat to Fusarium infection and trichothecene formation. Toxicology Letters 153: 37-46.

Van Sanford D.A., Clark A.J., Hershman D., Brown-Guedira G.L., Cowger C., Dong Y., Baik B.-K. 2016. Registration of „Pembroke 2014" soft red winter wheat. Journal of Plant Registrations 10: 41-46. 